\title{
Globális közjavak és davosi magaslatok - Simai Mihály 90 éves
}

\author{
„Lester C. Thurow The Future of \\ Capitalism (A kapitalizmus jövője) címü \\ munkájában azt a kérdést tette fel: »Kié \\ a parancsnoki pozíció a társadalmi rend- \\ szerről?« Mivel a kapitalizmus azt vallja, \\ hogy nincs társadalmi rendszer, a vála- \\ sza az, hogy senkié. Ezt azonban nem \\ tartotta elfogadható válasznak a XXI. \\ században. Thurow-nak véleményem \\ szerint igaza volt." (Simai [2016] 12. o.)
}

\section{Globális közjavak, ki vigyáz rájuk?}

Az, hogy a nagyon értékes, ugyanakkor véges globális közjavak léteznek, tudománytörténeti mércével mérve egészen fiatal gondolat, evolúciós értelemben pedig csak egy villanás. Az elmúlt évszázad hetvenes éveinek elején robbant be nagy erővel a tudományos köztudatba az a felismerés, hogy a Földön a gazdasági növekedés nem lehet határtalan. Közel fél évszázada az MIT négy fiatal kutatója a Római Klub alapítójának, Aurelio Pecceinek a felkérésére egészen egyszerü, de annál nehezebb kérdésekre keresett választ: mit jelent, ha a népességrobbanás korlátlanul folytatódik; milyen környezeti következményekkel jár a gazdasági növekedés; mit lehet tenni a Föld eltartóképességének növelésére; merre haladunk: egy fenntartható jövő vagy az összeomlás felé. Noha az eredeti és a harminc év után újrafogalmazott válaszok üzenete nagy óvatosságra intett, de alapvetően pozitív volt: megmutatta, hogy többféle lehetőség áll az emberiség előtt, és jelentős erőfeszítések árán ugyan, de összhang teremthető az ökológia és a gazdasági stabilitás között (Meadows és szerzötársai [2005]).

A tudomány e pozitív megállapítása mára alapvetően megváltozott; az aggódás és a gyors, egyúttal radikális cselekvés igénye fogalmazódott meg több fórumon is, föleg 
a párizsi klímaegyezmény összeomlása óta. A világ vezető gazdasági nagyhatalmai, de lényegében a világgazdaság egésze, az összes szereplö, kormányok, vállalatok és a fogyasztók valamennyien az idő szorításába kerültek. Az emberiség által a légkörbe kibocsátott szén-dioxid mennyiségének drasztikus csökkentése és általában a klímavédelem, nem tür halasztást.

Magyarországon az elmúlt hét évtizedben a globális világgazdasági átalakulások és az „emberiség nagy kérdéseinek” elmélyült tudományos kutatása leginkább Simai Mihály Széchenyi-díjas akadémikus munkásságához kötődik, akinek neve szinte összefonódott az ENSZ-szel. Leginkább úgy, mint a Magyar ENSZ Társaság elnöke, de úgy is, mint az ENSZ Társaságok Világszövetségének örökös tiszteletbeli elnöke, az UNICEF Kormányzótanácsának és az Európai Egyházak Konferenciájának az alelnöke, és mint aki az ENSZ fötitkárának különmegbízottjaként több globális kutatási témát irányított.

Pályafutásáról ma sem tudnánk jobb sommás összegzést adni, mint ami a 80. születésnapja előtt tisztelgő könyvben szerepel:

„Simai professzornak [...] már egészen fiatalon megvoltak azok a különleges elemzési és ítéletalkotó képességei, amelyek bonyolult [tegyük hozzá: hidegháborús évek és szigorúan kétpólusú világ - M. I.] nemzetközi környezetben is biztos eligazodást kínáltak. Nem lehetett véletlen, hogy még nem volt 30 éves, és már az ENSZ Európai Gazdasági Bizottságában dolgozhatott Genfben. A Világszervezethez való kötődése a mai napig elkísérte pályafutását. A kiemelkedően hosszú, egyben rendkívül eredményes életpályán mint kutató, mint tanár és mint tudományszervező egyaránt kivételes magasságokba emelkedett. Olyan példaadó pályát futott be, amelyre a saját, az előttünk járó és mögöttünk jövő generációk egyaránt őszinte nagyrabecsüléssel, sőt - mondjuk ki nyugodtan - némi ámulattal tekinthetnek. A mai, kifejezetten rohanó, a túl gyors átalakulásoktól meglehetősen zaklatottá vált egyetemi-kutatói-közéleti világunkban a mai napig fix pontként számíthatunk Simai professzor munkájára, a katedrán éppúgy, mint kutatóműhelyekben. Aligha kívánhatnánk neki mást, mint hogy még sokáig ejtse ámulatba az egyetemi hallgatóságot, vagy éppen az alma mater idősebb, már végzett hallgatóit, miként azt tette minden évben az általa oly nagy lelkesedéssel Budapesti Corvinus Egyetemen megszervezett, és meglepően nagy sikerűvé avanzsált Világgazdasági átalakulások című előadássorozattal.” (Blahó-Magas [2010] 10. o.)

Most, az újabb jeles évfordulón a Simai-életmű előtt tisztelegve csak a legutóbbi évtizedekben született munkáira reflektálunk. Föleg azért, mert - az elmúlt évek nemzetközi diplomáciai fejleményei és az „összeomlóban lévő globális kormányzás" miatt - napjainkban ezek a legaktuálisabbak, és talán izgalmasabbak, mint valaha. A kiemelkedő tudományos életmü első hat évtizedének rendkívül gazdag terméséröl részletes szakirodalmi áttekintést nyújt a professzor 80 . születésnapjára készült emlékkötet (Magas-Kutasi [2010]), ezért a továbbiakban Simai professzornak most csak a globális kormányzás és a közjavak, a zöldfejlödés esélyeiröl és a legújabb globális kockázatokról kifejtett nézeteit elemezzük, alapvetően a „globális közjavak védelmére” összpontosítva.

A globális kormányzással összefüggő kérdések régóta foglalkoztatták Simai Mihályt. Az egyik legnagyobb nemzetközi hatású munkája e témában (Simai [1994]) 
már az 1990-es évek közepén jelentős visszhangot váltott ki, föleg a globális kormányzással összefüggő új szemlélet kialakításának sürgetése miatt.

De újabb munkáiban is előveszi a máig megoldatlan globális intézményi problémák egy-egy fontos elemét, számba veszi a 21. századi jó és kevésbé sikeres ENSZgyakorlatokat. Legutóbbi könyvéböl megtudhatjuk, hogy a globális tudat egyidős valamilyen típusú globális együttmüködés/együttkormányzás igényének a felismerésével (Simai [2016]). Az emberiség fennmaradásának és a természetes fizikai környezete (a tengerek, az őserdők, maga a klíma, a világür) megóvásának igénye, annak felismerése, hogy a globális közjavak felügyelete, védelme és az e javak feletti rendelkezés mind-mind rendkívüli körültekintést igényel, és nélkülözhetetlenné teszi a nemzetek együttgondolkodását és közös cselekvését, globálisan elfogadott formában elsődlegesen az ENSZ keretein belül született meg.

„A környezeti vonatkozású globális kormányzás gyakorlatában a XXI. században fontos és sajátos területet alkotnak a globális közjavakkal kapcsolatos operatív tevékenységek. Történelmileg a legrégibb terület az óceánok és a tengerek »használatával« függ össze. A globális kormányzás az 1982-ben megkötött ENSZ Tengerjogi egyezményre épül, amely átfogó jogszabályok rendszere: kiterjeszti az államok területi jogait, meghatározza a halászattal és hajózással kapcsolatos szabályokat és a tengerfenékben rejlő ásványi kincsek kiaknázásának módozatait, feltételeit. [...] Az ENSZ államai, a körülötte kiépült tudományos és politikai civil szervezetek hálózata, a Világszervezet vezető testületei és személyiségei, részben a különböző programok végrehajtásának tanulságai, részben a bírálatok, de mindenekelött az új kihívások hatására, a XXI. század második évtizedében különösen jelentős erőfeszítéseket tettek a rendszer hatékonyságának növelésére. Ebben a folyamatban Pan Gimun (Ban Ki Mun), az ENSZ fötitkára véleményem szerint joggal nevezte sorsdöntő esztendőnek az ENSZ hetvenedik évfordulójának esztendejét a világ és az ENSZ számára." (Simai [2016] 340-341. o.)

Mindez nem jelentette azonban azt, hogy a világban kialakult volna egy egységes tudás és föleg közös megegyezés a globális közjavakkal való gazdálkodásról. Ráadásul a globális közjavak védelmével összefüggő elismert elvek és jó gyakorlatok tárháza meglehetösen terebélyes, és tudományos szempontból is csak nehezen áttekinthető. Az ENSZ szakosított szerveiben halmozódott fel a legtöbb általánosan, jobbára „politikamentesen” alkalmazható tudás és tapasztalat. A teljes politikamentesség azonban így sem garantálható. Noha az ENSZ - a Biztonsági Tanácsot kivéve - a világhatalmi játszmákban legfeljebb közvetítői szerepet tölt be, a globális közjavakkal való operatív gazdálkodás tekintetében növelni tudta befolyását és elismertségét is. Klímaügyekben azonban még nem tudott a kitüntetett közvetítöi-végrehajtói státusba emelkedni, amely egyébként megilletné. A jelen írás elején olvasható mottóban megfogalmazott kérdésre - „kié a parancsnoki pozíció a társadalmi rendszerről” - a tudomány részéről napjainkban sem született minden tekintetben megnyugtató válasz. A legnagyobb nehézséget ugyanis a közös, összehangolt globális cselekvés hiánya okozza mind a mai napig. Pedig a tudomány részéről az útkeresésben és a válaszadási kísérletekben nem volt hiány.

A világgazdasági koordinációs mechanizmusok jól dokumentálható közjószágkínálati kudarcai és föleg az Egyesült Államok klímaegyezmény-felmondása után 
igen tanulságos áttekinteni Simai professzor 2016-ban felvázolt, a globális koordinációs mechanizmusok kívánatos átalakításának esélyeit érintő gondolatait, amelyeket könyve, A gazda nélküli világ menedzserei (A fenntartható fejlődés jövője és a globális kormányzás) és A harmadik évezred nyitánya: zavarok, válságok, útkeresés címü részeiben ismerhetünk meg (Simai [2016] 9. és 10. rész). Ahogy azt Simai részletesen kifejti, a globális kormányzás (global governance) fogalmát először Harvan Cleveland amerikai közgazdász használta, aki a kifejezést a gazda nélküli világ menedzsmentjeként jellemezte. Rögtön hozzáteszi, hogy az angol governance szónak többféle jelentése is van: kevesebb mint kormányzás, de több mint szabályozás (Simai [2016] 290. o.). Később így definiálja a globális kormányzást:

„A globális szintű kormányzás tehát nem valamilyen központi felhatalmazással rendelkező világkormány müködésének és döntéseinek eredménye (ilyen ugyanis nem létezik), hanem különböző »funkcionális« területeken és szinteken folyó szervezett tevékenységek összessége, amelyekben mindazok a szereplők is részt vesznek, akik a társadalmak szervezeteit működtetik, vagy érdekviszonyainak, értékrendjének és vélemények közvetítői. Ezek a tevékenységek végső soron planetáris globális folyamatokban összesülnek. A globális kormányzásnak ezekre kell hatni, illetve következményeit kezelni.” (Uo. 290-291. o.)

Jól kivehető a diplomatikus megfogalmazásból, hogy ebben a globális kormányzási felfogásban „csak” két fö tényezővel van tartós probléma: a várhatóan jó és folyamatos koordinációval, továbbá a döntések kikényszeríthetőségével, a felelősséggel. Ezek a problémák nem változnak akkor sem, ha a globális kormányzás elfogadott, államok feletti szintjére lépünk, vagyis amikor az államok által elfogadott multilaterális együttmüködés hálózatát tekintjük. Ami számunkra, kutatók számára fontosabb, hogy ezt a koordinációs/felelősségi problémát tudományosan leíró diszciplína sem kiforrott. Ezért is történhet, hogy több tudományág egyszerre és gyakran egymást átfedve próbál választ adni ugyanazon nemzetközi elosztási, jogosultsági/fenntarthatósági dilemmára.

\section{Nemzeti, nemzetközi, globális és (világ)gazdaságtanok}

A közgazdaságtan hagyományos fejezetei és legfontosabb módszerei a nemzetgazdaság - azon belül is az államháztartás, a belföldi („,nemzeti”) vállalat és a hazai egyéb gazdasági szereplők (önkormányzatok, érdekvédelmi csoportok, szakszervezetek stb.) - gazdaságtanát igyekeznek leírni régről bevált és új fogalmakkal. Amikor azonban e szereplők a közvetlen földrajzi szomszédokkal vagy éppen távoli világpiacokkal lépnek tartós gazdasági kapcsolatokba, egészen új fejezeteknek kell tárgyalniuk az így kialakult nemzetközi müveletek logikáját, az érdekek harmonizációjának a folyamatait. Az elmúlt két évszázadban ezek a fejezetek is rendre megíródtak, és folyamatosan megújultak, mint például a nemzetközi gazdaságtannak a kereskedelem, illetve a pénzügyek szféráján belüli kitüntetett területei.

Egy nemzetgazdaság, illetve annak szereplői és a világgazdaság egyéb intézményi résztvevői közötti kölcsönhatások elemzése - az esetek többségében - ma is 
leginkább az angolszász közgazdasági kultúrkörből ismert, s mára már a Kelet- és Közép-Európában is megszokottá vált mikro- és makroökonómiai fogalmi eszköztárral, de hangsúlyozottan a nemzeti kormány és költségvetésének, a belföldi vállalat gazdálkodásának, a nemzeti fogyasztó/termelő jólétének a szemszögéből történik. Különbség jórészt csak abban van, hogy nagy, közepes vagy kis, nyitott nemzetgazdaság az elemzés vizsgált egysége.

Ez a dominánsnak - vagy divatosabb kifejezéssel: föáramúnak (mainstream) is nevezhetö szemlélet a nemzetközi kereskedelmi és pénzügyi kapcsolatok, illetve a nemzetállamok elmúlt két évszázados történelme alapján teljesen indokolt. A világ, pontosabban a világgazdaság - amit az abban részt vevő nemzetgazdaságok és egyéb globális szereplők sajátos együtteseként értelmezünk - azonban már jó néhány évtizede eljutott egy olyan stádiumba, amelyben némiképp más szemléletben is muszáj gondolkodni magáról az egész világgazdasági rendszerről is. E nemzetektől „független”, globális gondolkodás során részben más fogalomhasználattal is kell élnünk. Meg kell ugyanis értenünk a nemzetközi gazdasági folyamatkomplexumnak azokat az általános, az egészre jellemző viselkedési jellegzetességeit, amelyeket például egy külső megfigyelő bizonyosan egy sajátos „rendszernek” tekint. Ide kell érteni a belülről nehezen vagy egyáltalában nem látható rendszerkockázatokat, tehát azokat az esetleges negatív fejleményeket is, amelyek a bekövetkezésük esetén egyetemlegesen sújthatnak minden résztvevőt, a nemzeti hovatartozásuktól teljesen függetlenül. Ezeknek a világgazdasági folyamatoknak a különös összetettségét és gyorsan változó jellegét hangsúlyozó munkáknak sorába illeszkedik Simai professzor két itt tárgyalt könyve is (Simai [2007], [2016]).

A világgazdasági folyamatokról kialakított rendszerelvü gondolkodás igénye mára - legalábbis a tudomány számára - a klímavédelem ügyén túlmenően is alaposan felerösödött. Ebben jelentős szerepet kaptak az ENSZ szakosított szervezetei. Ennek a megállapításnak remek, magyar nyelvü tudományos dokumentációját is megtalálhatjuk Simai Mihály 2016-ban publikált könyvében, amelyben a szerző az ENSZ és a szakosított nemzetközi szervezetek által támogatott - a különösen a fenntartható fejlödés és a környezetvédelem ügyeiben jelentkező - globális együttmüködési folyamatoknak, a globális kormányzásnak kiváló eseményés eszmetörténeti áttekintését adja. A sok kritikát ellensúlyozandó, a könyvben egyértelmüen pozitív fejleményekről is beszámol, amennyiben már a 2012-es ENSZ-világkonferencia $($ Rio +20$)$ a korábbiakhoz képest jóval gyakorlatiasabb és végrehajthatóbb fenntartható fejlődési célokat határozott meg A jövő, amit mi akarunk (The Future We Want) címmel. Mi több, a tagállamok jelentős pénzügyi elkötelezettséget is vállaltak, az energiaellátás kiszélesítését és zöldítését szolgáló programokhoz pedig nemzetközi fejlesztési bankok és magántársaságok is csatlakoztak. Az ENSZ tehát a Rio + 20 világeseményen már jóval sikeresebben lépett fel mint globális gazdasági „matchmaker”, koordinátor. Az előrelépésnek azért még bőven maradt tere.

Az ENSZ által elindított, globálisan is pozitív koordinációs lépések nyomán talán az is belátható, hogy a változó világgazdasági környezethez való alkalmazkodás során nemcsak a vállalatok, hanem remélhetően a gazdaságpolitikáért felelös 
kormányzatok is tanulnak a múlt hibáiból. Igaz, jóval lassabban, mint kellene, és ahhoz képest is lassan, ahogyan erre a belföldi választóik kényszerítik őket. Ebben az értelemben a globálisan egyeztetett makropolitikák esetében is egy evolutív tanulási folyamatról beszélhetünk, amelybe már - bár nagyon lassan - a globális igények is beépülnek. Ha az belátható, hogy a belföldi piacaikon még a legfejlettebb nemzetgazdaságok sem képesek kielégítő önkorrekciókra és a negatív externáliák kompenzálására (márpedig nem képesek), akkor a világgazdaságban a globális folyamatok kedvező kimenete még kevésbé várható pusztán az önkorrekciós vagy a csak piaci koordinációs mechanizmusoktól. Ebben a felfogásban a globális intézményi, nem piaci koordináció létjogosultsága is nagy erővel tör tehát felszínre, e létfontosságú, világgazdasági koordinációs mechanizmusok kialakításához pedig új gondolkodásra és részben új intézményekre is szükség van. Ezt Simai Mihály oly sok munkájában maga is szorgalmazta, különösen A világgazdaság a XXI. század forgatagában címü könyvében, kiemelten annak A világgazdaság mikroszférája a XXI. század elején című negyedik, valamint A transznacionális társaságok irányítási és stratégiai döntési rendszere a globális versenyben címü ötödik részében (Simai [2007]). Továbbá újabb könyvének 8. részében, amelynek címe: „A negyedik ipari forradalom", fenntartható gyáripari fejlődés vagy újraiparosítás? Stratégiák és szereplők az iparpolitikákban (Simai [2016]).

\section{Davosi magaslatok}

Az ENSZ kiterjedt és általánosan elismert, ugyanakkor gyakran átpolitizált közjavakat védő tevékenysége mellett már az 1970-es évek elején elindultak nem kormányokhoz, hanem a magánszektorhoz és magához a tudományhoz kötődő nemzetközi fórumok. Davosban 1971 óta az akkor még csak 32 éves német mérnök-közgazdász ötletgazda, Klaus Schwab szervezésében kerül megrendezésre minden évben - 1987-től Világgazdasági Fórum (World Economic Forum, WEF) elnevezéssel - az a világkonferencia, amely az indulása óta eltelt fél évszázadban valódi világeseménnyé nőtte ki magát, és amelynek rangja a résztvevők ismertségének következtében hihetetlen magasságokba emelkedett, világméretü nemzetközi médiafigyelmet vonzva évről évre. A festői magaslati környezetben tartott konferencia eredeti küldetése lényegében nem változott: „elkötelezettség a világ állapotának jobbításáért” (committed to improving the state of the world). A WEF a globális közjó érdekében hozza össze az üzleti világ tényleges tulajdonosait, valamint az általuk érintett, szélesebb értelemben vett társadalmi szereplőket (stakeholders), továbbá a politika és - természetesen, a legnagyobb szerencsénkre(!) - a tudomány képviselőit, hogy így együtt, oldottabb (igaz, luxus-) körülmények között, vitassák meg a legégetöbb globális kérdéseket. Ebben az évben ezek egyike éppen a klímaváltozás volt, amelynek jelentőségét nagyon nehéz túlértékelni. Meg is született az a kezdeményezés, amely ezermilliárd(!) új fa ültetését szorgalmazza világszerte. 
Kár lenne tagadni, hogy a tudomány vonzereje Davosban is csak nehezen vetekedhet a sztárdöntéshozók, kormányfők és a világcégek befolyása által képviselt erőkkel. Pedig az emberiség ősrégi, sajnos gyakran drámaian szomorú tapasztalata igazolja, hogy márpedig a tudomány müvelőire is érdemes hallgatni, globális természettudományos ügyekben éppúgy, mint feszítő Társadalmi kérdésekben. A davosi Világgazdasági Fórum ezt korán felismerte, és jelentőségét az egész világgal el is hitette, hiszen valójában a WEF-márka értéke és a WEF csillapíthatatlannak tűnő médiasikere is éppen ebben a különleges, háromoldalú (globális vállalat, nemzeti kormányok és a tudomány) informális eszmecsere-sorozatban fejeződik ki. Mind nagyobb, a szó legszorosabb értelmében vett globális elfogadottsága jó eséllyel avval függ össze, hogy a világ magán- és közösségi szereplői között sikerült létrehoznia egy, leginkább az ENSZ-re jellemzö, az „EMBERISÉG NAGY ÜGYEIT” képviselö, ugyanakkor perspektivikus gondolkodást. Talán fokozottan is igaznak tetszhet ez a megállapítás most, egy olyan időszakban, amikor a globális kormányzás összeomlani látszik.

A világot éppen fenyegető koronavírus-járvány idején a WEF-típusú szerveződések jelentőségét is mutatja, hogy éppen húsz évvel ezelött Davosban született meg az a Globális Szövetség a Vakcinákért és az Immunizációért (Global Vaccination Alliance, GVAI), amely egy remek, nem állami összefogás intézményét teremtette meg a világ talán legértékesebb közösségi jószágaként felfogható népegészségügyben. Természetesen ez nem jelenti azt, hogy az Egészségügyi Világszervezet (WHO) befolyása és tekintélye akár szemernyit is csökkent volna, sőt az emberiség tőle elfogadja, hogy most a koronavírus a legnagyobb ellensége.

Ezen a ponton lehet és szinte kötelező újra összekapcsolni Davost, a WEF-et, a magyar tudomány világgazdasági kutatásait és Simai Mihály akadémikus kivételes, azt is mondhatnánk, lélegzetelállítóan gazdag, hét évtizedes(!), a világgazdaság nagy átalakulásaival és az ENSZ-szel összeforrott munkásságát. A fiatal magyar kutató a genfi nemzetközi ENSZ-fórumokon szinte davosi magaslatokon járt. Tudományos tevékenysége, termékenységét, gondolati mélységét tekintve, egészen egyedülálló, a témakörök hasonlósága alapján azt is mondhatnám: davosi magaslatokba emelte.

Végezetül egy személyes élmény. Éppen tíz évvel ezelőtt, amikor a Budapesti Corvinus Egyetemen, a zsúfolásig megtelt III-as előadóban egy konferencián ünnepeltük a Simai-életmü elöző nagy évfordulóját, jómagam - levezető elnökként eléggé nehezen találtam a szavakat. Ö, az ünnepelt segített ki, megjegyezve, hogy rengeteg ismerős van a teremben, akikkel egyetemi évei alatt, az előadásokat követően, éppen itt milyen jókat ultizott... Nos, ez a csipetnyi humor és természetesség azonnal oldotta a feszültségemet. Most pedig, ezen a 90. évfordulón még nehezebben találom a megfelelő zárószavakat. Nem is keresem tovább az életművét jól leíró jelzőket. Ellenben nyilvánosan megígérem, hogy a következő „,nagy” évfordulóra találok még valami különlegeset. Simai Mihály munkásságát sokáig közelről figyelve - és munkatársaként is -, mindenkivel megosztom azt a sejtésemet, hogy a tudományos kutatás és a humor nagyon jó eséllyel segítenek fiatalnak maradni. 
Zárógondolatként Goethe Faustjából merítek:

„BOLDOG FIÚK KARA
(a legmagasabb csúcsok körül keringve)
Fonódjanak hát
víg láncba karjaink,
zengjünk zsolozsmát,
perdüljünk táncra mind!
Bízzunk: nekünk a
legföbb tudás jut;
kit tisztelünk ma,
majd látva látjuk.”
(Goethe [1832/2012] o.)

\section{Hivatkozások}

BLAHó AndRÁs-Magas István [2010]: A magyar világgazdasági kutatások élvonalában hat évtizeden át. Simai Mihály nyolcvanéves. Megjelent: Magas-Kutasi [2010] 10. o.).

Goethe, J. W. [1832/2012]: Faust. Jékely Zoltán-Kálnoky László fordítása. Európa Könyvkiadó, Budapest.

Magas István [2017]: A nemzetközi gazdasági folyamatok rendszerszintű dilemmái. Külügyi Szemle, 16. évf. 4. sz. 121-146. o.

Magas IstváN-KutAsi GáboR (szerk.) [2010]: Változó világgazdaság. Globális kormányzás - vállalati nemzetköziesedés - regionális fejlődés. Tanulmányok Simai Mihály 80 . születésnapjára. Budapesti Corvinus Egyetem, Budapest.

Meadows, D.-Randers, J.-Meadows, D. [2005]: A növekedés határai - harminc év múltán. Kossuth Kiadó, Budapest.

Simai Mihály [1994]: The Future of Global Governance. Managing Risk and Change in the International System. Washington D.C.

Simai Minály [2007]: A világgazdaság a XXI. század forgatagában. Akadémiai Kiadó, Budapest.

Simai Minály [2016]: A harmadik évezred nyitánya. A zöld fejlődés esélyei és a globális kockázatok. Corvina Kiadó, Budapest.

Thurow, L. [1997]: The Future of Capitalism. Penguin Books, New York, NY.

Magas István

Magas István, az MTA doktora, egyetemi tanár, a Budapesti Corvinus Egyetem Világgazdasági Tanszékének korábbi vezetője. 